\title{
Within tree distribution of a gall-inducing Eurytoma (Hymenoptera, Eurytomidae) on Caryocar brasiliense (Caryocaraceae)
}

\author{
Germano Leão Demolin Leite ${ }^{1}$, Ronnie Von dos Santos Veloso², Farley Willian Souza Silva ${ }^{1}$, \\ Rafael Eugênio Maia Guanabens ${ }^{1} \&$ G. Wilson Fernandes ${ }^{3}$
}

${ }^{1}$ Universidade Federal de Minas Gerais, Av. Universitária n. 1000, B. Universitário, 39404-006, Caixa Postal 135. Montes Claros-MG, Brazil.
gldleite@ica.ufmg.br.
2Departamento de Biologia Animal, Universidade Federal de Viçosa, 36571-000 Viçosa-MG, Brazil. ronnievond@ yahoo.com.br
${ }^{3}$ Ecologia Evolutiva \& Biodiversidade, Caixa Postal 486, ICB/Universidade Federal de Minas Gerais, 30161-970 Belo Horizonte-MG, Brazil.
gwilson@icb.ufmg.br

\begin{abstract}
Within tree distribution of a gall-inducing Eurytoma (Hymenoptera, Eurytomidae) on Caryocar brasiliense (Caryocaraceae). For the first time, we identified the insect herbivore that induces one of the most conspicuous galls on the leaves of Caryocar brasiliense Camb. (Caryocaraceae), a widespread, typical cerrado woody plant of large economic importance. The gall inducing organism is a new and undescribed species of Eurytoma sp. (Hymenoptera, Eurytomidae). Furthermore, we recorded its spatial distribution within C. brasiliense trees. More Eurytoma galls were found on the eastern tree slope, followed the southern and northern slopes. More galls were found in the interior of the tree crown, i.e., on the proximal portion of the stems compared to the terminal portion. At the leaf level, more galls were found on the median region compared to the distal or proximal, perhaps due to the lower trichome density found in there. Leaf colonization by Eurytoma sp. may initiate at the leaf margin but after colonization reaches $50 \%$ the central portion starts to be colonized.
\end{abstract}

KEYWORDS. Cerrado; insect distribution; insect galls; pequi, trichomes.

RESUMO. Distribuição espacial de galhas induzidas por Eurytoma (Hymenoptera, Eurytomidae) em plantas de Caryocar brasiliense (Caryocaraceae). Pela primeira vez foi identificado o inseto herbívoro que induz uma das galhas foliares mais conspícuas em Caryocar brasiliense Camb. (Caryocaraceae), uma planta amplamente distribuída no Cerrado brasileiro e de relevante importância econômica. O galhador identificado, preliminarmente, como uma nova espécie ainda não descrita de Eurytoma (Hymenoptera, Eurytomidae). Além disso, foi observado a distribuição espacial desse galhador na copa das árvores de C. brasiliense. O lado leste da planta apresentou maior abundância de galhas de Eurytoma sp. seguido pelos lados sudeste e nordeste. No interior da copa houve um maior número de galhas em relação à porção mais externa. Em relação às folhas, a maior abundância ocorreu na porção mediana comparada às regiões proximal e distal, provavelmente devido ao menor número de tricomas na porção mais central da folha. Após colonizar cerca de $50 \%$ das folhas marginais Eurytoma sp. inicia a colonização das folhas na porção central da folha.

PALAVRAS-CHAVE. Cerrado; distribuição espacial de insetos; insetos indutores de galhas; pequi; tricomas.

Insect galls are known to distribute differentially within host organs. Many galling larva achieve higher density, size, and even higher performance at the proximal portion compared to more distal portion of the leaf. For instance, Pemphigus betae Doane (Hemiptera, Aphididae) individuals that induce galls on the most proximal portion of the leaves of Populus angustifoliae James (Salicaceae) reach higher fitness compared to those that attack the distal parts of the leaves (Whitham 1978; but see Auslander et al. 2003). The mechanism that influences this differential within leaf distribution was argued to be the more rapid and efficient interceptation of plant photosynthates at the leaf base (Whitham 1978). In a similar way, galls induced by the beetle Collabismus clitellae Boheman (Coleoptera, Curculionidae) are also more abundant and larger at the basal portion of the stems of its host plant Solanum lycocarpum St. Hil. (Solanaceae) (De Souza et al. 1998, 2001); where galls reach larger sizes perhaps due to stronger sinks in this region of the plant.

Insect galls may also distribute differentially between habitats as well as within the host crown. Plants in sunny habitats are known to support higher density of galls compared to plants in shaded habitats (Hartman 1984; Fernandes \& Price 1992; Auslander et al. 2003). The abundance of a lepidopteran gall on Tetradymia DC. (Asteraceae) was higher on the sunlight-exposed foliage (Hartman 1984). Differential sun exposure may influence the quality of the host plant tissue as well as the gall tissue or even the plant ability to find and elicit induced responses to the invading organism (see Fernandes 1990; Fernandes et al. 2000, 2005). Furthermore, natural enemies could also be strong selective forces against galling on more favorable, shaded habitats (see Fernandes \& Price 1992). Therefore, differential selection could lead to female preference and larval performance for foliage in sunny habitats.

Caryocar brasiliense Camb. (Caryocaraceae) is one of the most common and important plant species in the dry and harsh semi arid vegetation of Brazil, called cerrado. It is host to a large number of invertebrate and vertebrate herbivores (e.g., Oliveira 1997; Lopes et al. 2003). Among the insect herbivores 
that attack $C$. brasiliense, a gall-inducing hymenopteran is the most abundant species in the cerrado of northern Minas Gerais State, Brazil. This gall is induced by a still undescribed species that cause premature leaf abscission when at high density (Oliveira 1997).

In an effort to initiate ecological studies in this system, we reared adults of this galling insect herbivore to identify the inducing species and obtained the first data on its spatial distribution at the tree level. We asked whether gall abundance would differ among the leaflets on a single leaf and observed the effect of foliage slope orientation on gall abundance. Then we described the distribution of the galls on the leaves along the host stem (within tree). Because the grouping of galls on a given leaf portion may indicate site preference (Whitham 1978), we analyze the within leaf (longitudinal and transversal) distribution of galls and observed whether leaf gall distribution was influenced by leaf trichome abundance.

\section{MATERIALAND METHODS}

The study was done at a locality known as "Abóboras", in Montes Claros, MG, Brazil (43 55' 7.3" W, $16^{\circ} 44^{\prime}$ '55.6"S, 750m a.s.l.). The north of Minas Gerais State has a climate Aw: tropical of savanna, according to the classification of Köppen, with dry winter and rainy summer. The vegetation is Cerrado (savanna) under several human disturbances, and the soil is red dystrophic yellow latosoil of loamy texture. During the field study the average temperature was $22.7^{\circ} \mathrm{C}$; air relative humidity $68.7 \%$, year round accumulated precipitation of $1292.6 \mathrm{~mm}$; winds prevailed from the northeast at an average speed of $2.36 \mathrm{~m} / \mathrm{s}$; insolation $8.0 \mathrm{~h}$.
One of the most conspicuous species of the Cerrado vegetation is the tree Caryocar brasiliense Camb. (Caryocaraceae), locally known as "pequi" (Sano \& Almeida 1998). This species is widely distributed in the Cerrado (Brandão \& Gavilanes 1992). Its wood is used in house and furniture construction due to its durability, while its fruit represents an important economic resource (Almeida et al. 1998; Ribeiro 2000, Lopes et al. 2003).

To obtain the adult gall and associated insects we collected 100 highly infested leaves of 10 haphazardly selected trees in the field ( $\mathrm{n}=1,000$ leaves). Leaves were placed in plastic jars and rearing took place in an incubator at a constant temperature of $25^{\circ} \mathrm{C}$. Observations were made every week for a month. Reared insects were placed in vials containing $70 \%$ alcohol and sent for identification by taxonomists. To ascertain the identity of the gall-inducing insect we caged two mating pairs of the species with young $C$. brasiliense individuals under greenhouse conditions. Cages $(n=3)$ were constructed of plastic bottles ( 2 litter) covered with fine nylon mesh (at the bottom) to avoid insects to leave the plastic cage or enter it. Plants were carefully examined for galls prior to the beginning of the experiment. Galls were successfully induced two days later and from 30-40 days later only eurytomids emerged from them.

As the gall density of our study species per leaf was highly variable among leaves, all data were reported considering the area of the leaf taken by the galls. Caryocar brasiliense has three leaflet compound leaves. To evaluate the distribution of galls within the tree crown we recorded the number of galls on the compound leaves of $C$. brasiliense of four randomly selected stems positioned (Fig.1A) on north, south, east, and
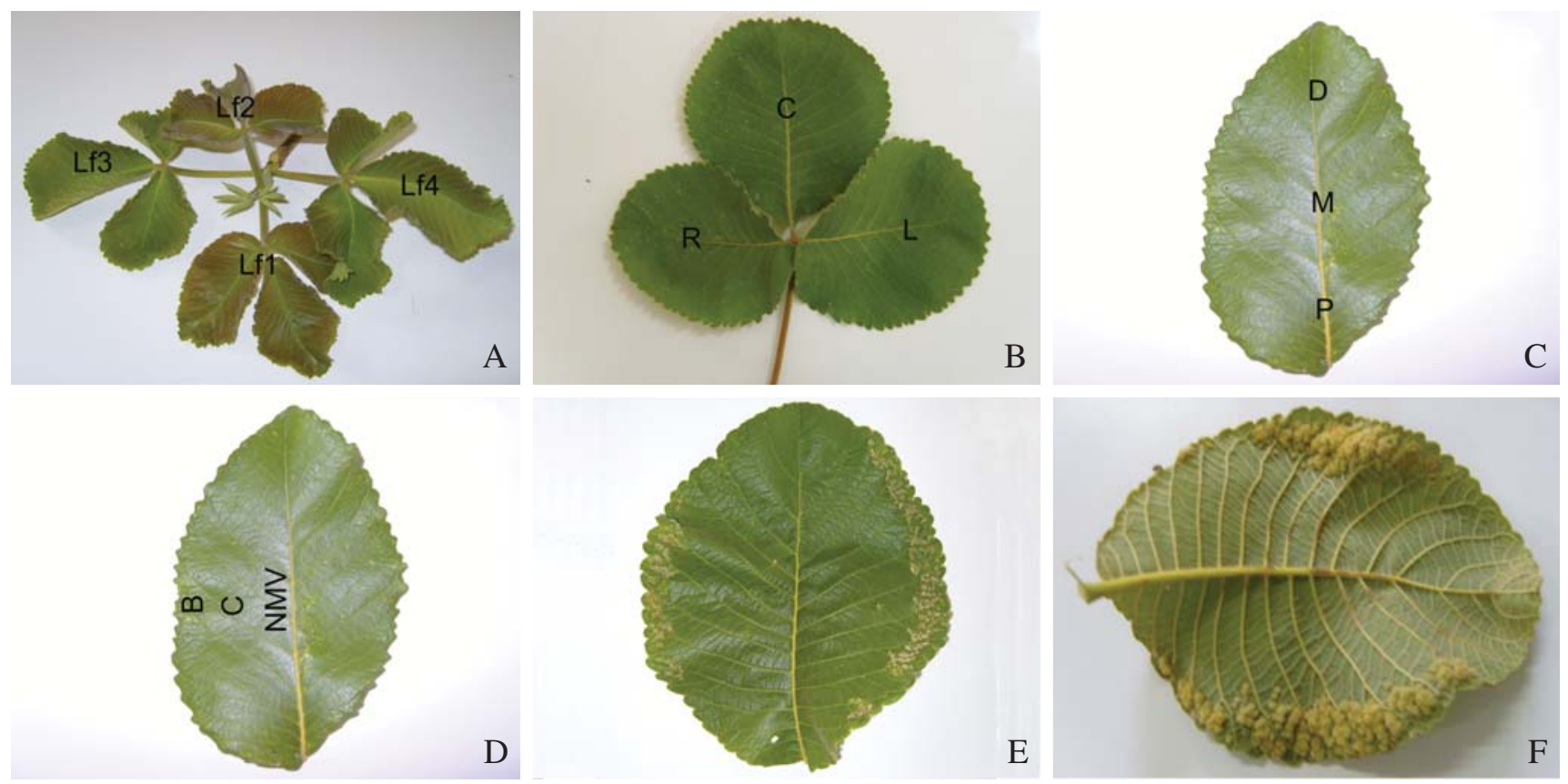

Fig. 1. A. Position of leaves on a stem, Lf 1: leaf 1, Lf 2: leaf 2, Lf 3: leaf 3, and Lf 4: leaf 4; B. leaflet position on leaf, L: left, C: central, and R: right; C. Longitudinal regions on a leaflet, D: distal, M: median, and P: proximal; D. Transversal position on a leaflet, B: border, C: central, and NMV: near the mid vein; E. Young galls induced by Eurytoma sp. on Caryocar brasiliense; F. old galls induced by Eurytoma sp. on Caryocar brasiliense. 

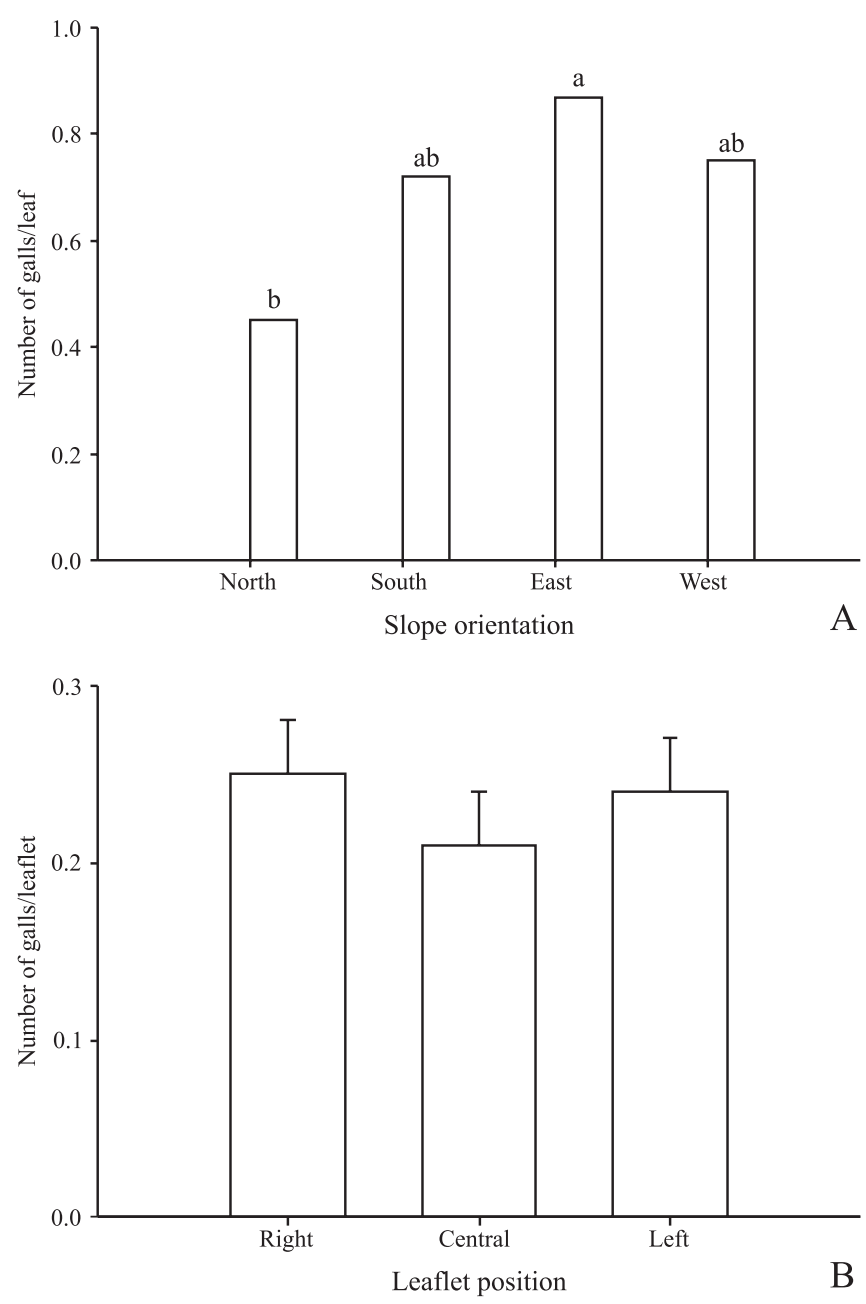

Fig. 2. Abundance of galls induced by Eurytoma sp. on Caryocar brasiliense. A, number of leaf galls induced according to stem orientation. $\mathrm{B}$, number of galls induced on the three leaflets of Caryocar brasiliense. Averages followed by the same letters or without letters did not differ statistically.

west facing sides of ten adult trees (average height: $4.9 \pm 0,1$ $\mathrm{m}$; average crown width: $3 \cdot 2 \pm 0,1 \mathrm{~m}$ ). The leaflets censused were classified according to the percent of the leaf area covered by the galls as $0,5,10,20,30,40,50,60$, and $70 \%$. To evaluate the distribution of galls among the leaflets we recorded: i) gall abundance according to foliage orientation (slope); ii) the differential abundance of galls on the right, central and left leaflets (Fig.1B); iii) gall abundance on the distal, median, and proximal region of a leaflet (Fig.1C); and iv) gall abundance on the leaflet border, central area, and adjacent to the mid leaf vein of the leaflet (Fig.1D). 4,320 leaflets of 1,440 leaves were censused for galls.

To evaluate the possible effects of trichomes on the distribution of galls among the leaf zones we recorded the density and type of trichomes present on the adaxial and abaxial leaf laminas. One leaf on each stem position (one to four) was sampled at each slope orientation ( $\mathrm{n}=10$ individuals). On nine squares of $0.60 \mathrm{~mm}^{2}$, we recorded the type and density of trichomes of the three leaflet longitudinal zonation (distal, median, and proximal). The same observations were done for the trichomes along the leaf transverse zonation (border, central, adjacent to the midvein). All data were analyzed by analysis of variance and followed by the Tukey test at the significance level of $\alpha=0.05$.

\section{RESULTS}

Galls were induced by a new species of Eurytoma (Hymenoptera, Chalcidoidea, Eurytomidae) (MAP Azevedo, pers. com.). Identical galls of those found in the field were induced by mating pairs of Eurytoma sp. in the caging experiment, indicating that this species is indeed the galling organism. No other insect emerged from these galls induced inside cages.

Galls are induced on young, expanding leaves of $C$. brasiliense. The gall is spheroid, yellowish, with short hairs on the adaxial leaf surface (Fig.1E, F). It has only one chamber where a single larva is found. Wasp females were easily seen ovipositing on unfolded leaves in the field. Approximately two days later the inducing site became reddish and a visible gall was observed a few days later. Many insects emerged from the galls collected in the field, as follow: Sycophila sp. (Hymenoptera, Eurytomidae) - Eurytoma parasitoid); Ablerus magistretti (Hymenoptera, Aphelinidae) - Eurytoma parasitoid); Quadrastichus sp. (Hymenoptera, Eulophidae) probably a hyperparasitoid of Sycophila sp; and finally one single individual belonging to the tribe Alycaulini (Diptera, Cecidomyiidae) - probably a gall inquiline.

The average number of galls varied according to slope orientation of the tree crown. More galls were found on the eastern slope compared to the other slopes (Fig. 2A) while fewer galls were found on the foliage in the northern slope. On the other hand, the average number of Eurytoma galls did not differ statistically among the three leaflets of $C$. brasiliense $($ right $=0.25$, central $=0.24$, left $=0.21$, Fig $2 B)$.

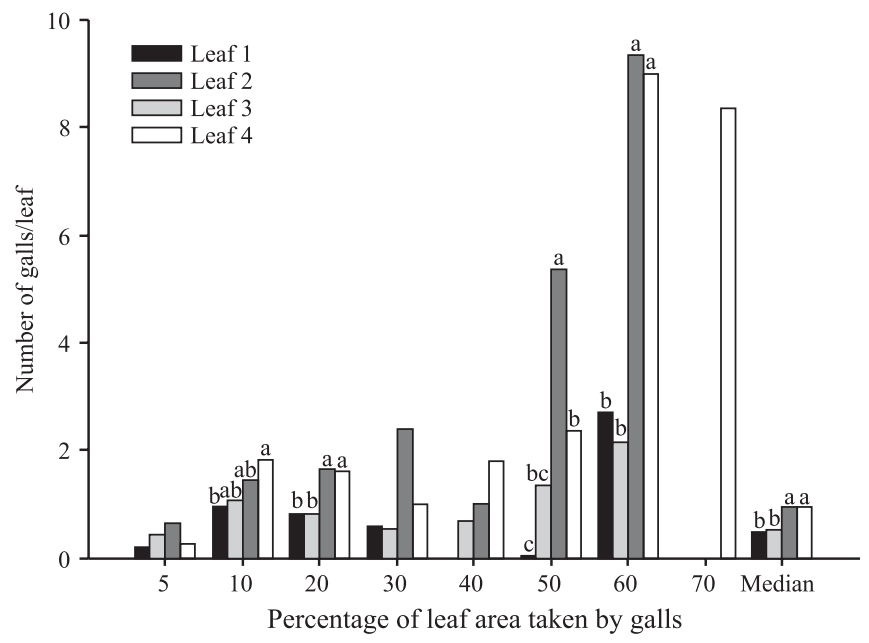

Fig. 3. Number of galls induced by Eurytoma sp. on the first four leaves of Caryocar brasiliense according to the percentage of leaf area covered (occupied) by the galls. Averages followed by the same letters or without letters did not differ statistically. 


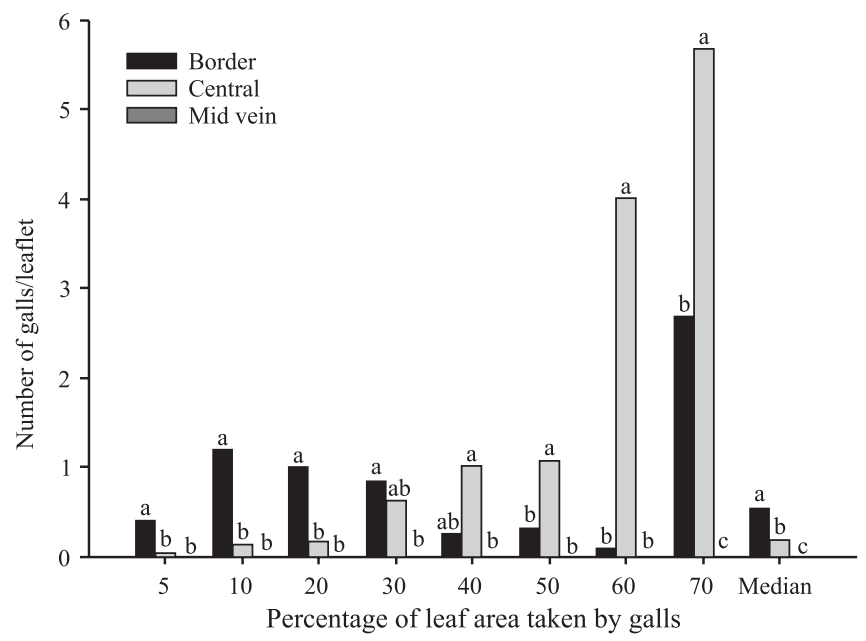

Fig. 4. Number of galls induced by Eurytoma sp. on the border, center and near the mid vein leaflet portions of Caryocar brasiliense according to the percentage of leaf area covered (occupied) by the galls. Averages followed by the same letters or without letters did not differ statistically.

More galls were found on the leaves in the interior of the tree crown than at the border on all categories of leaf area taken by the galls. Leaf positions 3 and 4 supported $66.7 \%$ of all galls sampled (Fig. 3).

A trend existed for more Eurytoma galls on the leaf margin (0.52) compared to the other transversal leaf areas (Fig. 4). Only after the percent cover of galls reached 50\%, the central portion of the leaf began to be colonized. No gall was found near the mid vein.

More galls were found on the median region of the leaf compared to the other areas (Fig. 5). Otherwise, under a severe infestation level ( $70 \%$ of the leaflet area taken by the galls) galls became abundant on the distal leaf portion.

All trichomes of $C$. brasiliense are non-glandular, simple and multicelular. They were on average $176.67 \mu \mathrm{m}$ long in the adaxial lamina while they averaged $241.21 \mu \mathrm{m}$ on the abaxial lamina. The density of trichomes was higher on the leaf margin than on the other tranversal leaf portions (Fig. 6). The distal and median leaf portions presented lower trichome density than the proximal portion (Fig. 6).

\section{DISCUSSION}

Galls were induced by a new species of Eurytoma, indicating that the other insects reared from galls collected in the field can be regarded as parasitoids and/or inquilines. Species of the genus Eurytoma can be gallers (Askew \& BlascoZumeta 1998), parasitoids (De Santis \& Fernandes 1989; Edwards 1998; Eliason \& Potter 2001; Georgiev \& Stojanova 2003; Johannesen \& Seitz 2003), hyperparasitoids (Tagawa \& Fukushima 1993), or even gall inquilines (Roininen et al. 1996; Hayman et al. 2003). Yet in some cases Eurytoma species may have both an entomophagous and phytophagous behavior. For instance, Hale et al. (2004) reported a cynipid gall parasitoid, Eurytoma brunniventris Ratzeburg, feeding both on the gall inhabitants and gall tissue.
As eurytomids are generally small insects, there is a possibility that wind may have played an important role in their within tree distribution. The dispersion of many insects is strongly influenced by wind direction (Pathak et al. 1999; Tixier et al. 2000; Schooley \& Wiens 2003; Feng et al. 2004, 2005). As the prevalent winds in the region are northeasterlies/ easterlies (data from the Main Climatic Station of Montes Claros), we postulate that the foliage on the eastern slope of the host trees are the most exposed to higher winds and strong sunlight. These observations corroborate previous findings in which gallers are most abundant on sunlight-exposed foliage (see Hartman 1984; Fernandes \& Price 1988). At a smaller scale, no difference in gall abundance was found when the leaflet position was taken into account. Otherwise, future studies shall address the differential success and mortality of gallers within the crown to elucidate the mechanisms involved.

More galls were found on the leaves in the interior of the tree crown than at the border on all categories of leaf area taken by the galls. Several mechanisms may influence the trend found. First, differential mortality caused by parasitoids, predators, and even differential plant resistance could diminish the galling success on the more proximal region of the stems. Even if females prefer leaves at the border, stronger selective pressures would impair their success at such habitat. An alternative hypothesis is that the most distal leaves (leaves 1 and 2) were too young to be found by the gallers while leaves 3 and 4 were exposed to galling for a longer period. Only more detailed field studies would solve this question.

A trend existed for more Eurytoma galls on the leaf margin compared to the other transversal leaf areas. Although the density of trichomes was higher on the leaf margin than on the other tranversal leaf portions, extrafloral nectaries were also mostly frequent on the leaf margins (Rezende 1998). The role of extrafloral nectaries on the host plant interaction with galling insects is not known. Otherwise, we postulate that they might

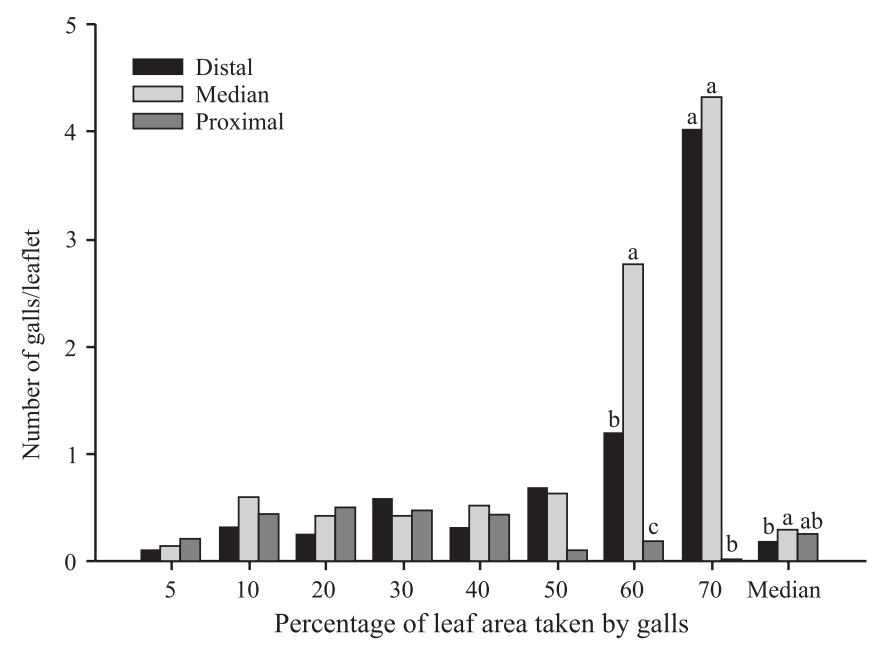

Fig. 5. Number of galls induced by Eurytoma sp. on the distal, median, and proximal leaflet portions of Caryocar brasiliense according to the percentage of leaf area covered (occupied) by the galls. Averages followed by the same letters or without letters did not differ statistically. 

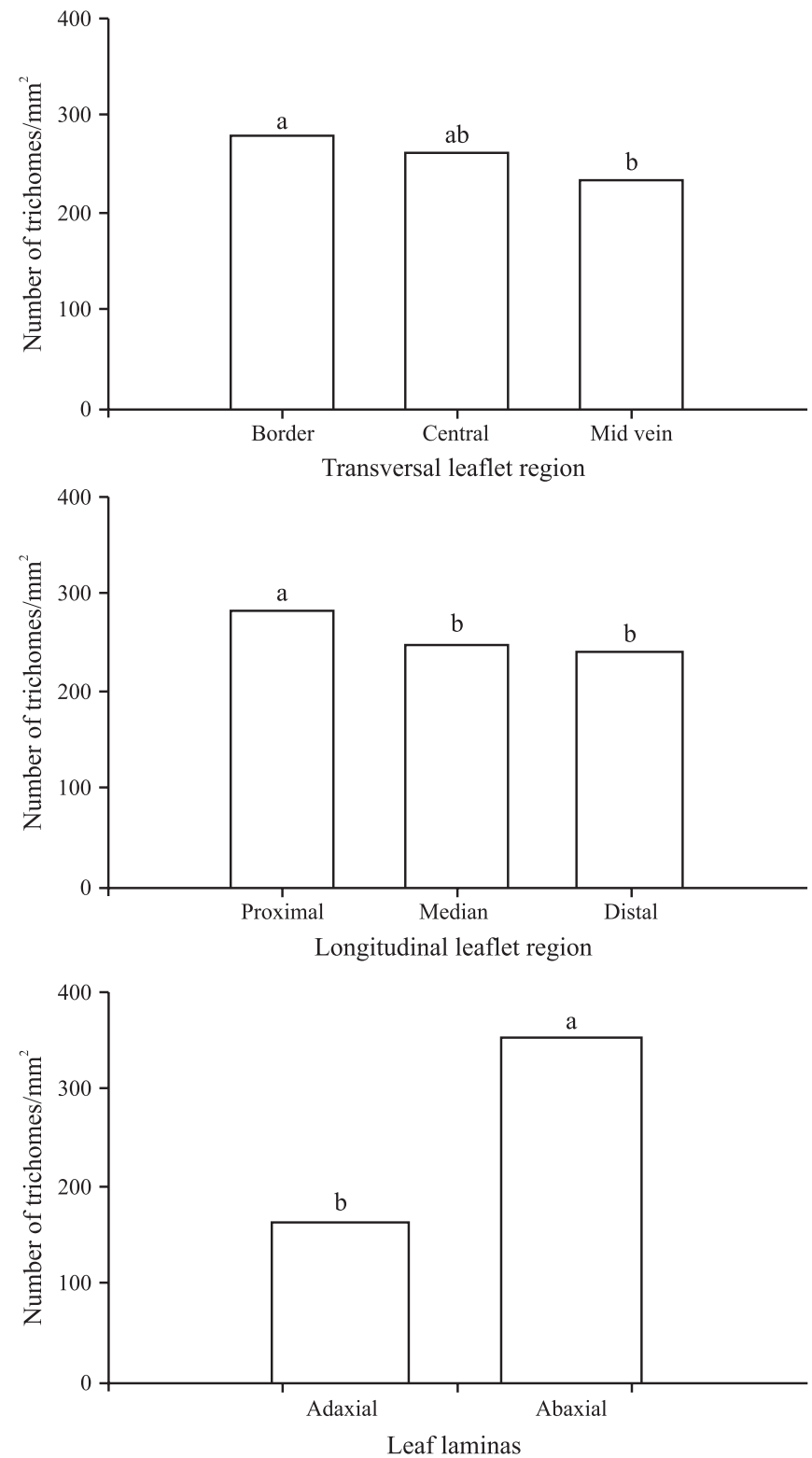

Fig. 6. Number of trichomes $/ \mathrm{mm}^{2}$ in Caryocar brasiliense leaflets on the transversal and longitudinal leaflet regions in the adaxial and abaxial leaf surfaces. Averages followed by the same letters or without letters did not differ statistically.

influence the Eurytoma female preference as they may have an indirect positive role in protecting the galling insects against natural enemies by attracting ants. Ants were reported to be associated with the leaf trichomes of Caryocar (Oliveira 1997) and in the studied plants they were commonly seen associated with the leaf extrafloral nectaries. Although rarely studied, ants have an interesting and important role with gall inducing insects, worth to be studied in detail (see Fernandes 1994; Fernandes et al. 1999).

More galls were found on the median region of the leaf compared to the other areas. The higher abundance of galls on the leaf lamina could be influenced by trichome density. Females may prefer to oviposit on leaf regions where trichomes are at lower density as reported for the leafminer Liriomyza trifollii (Burgess) (Diptera, Agromyzidae) (Hawthorne et al. 1992). Lower oviposition and adult feeding by L. trifollii on wild tomato Lycopersicon pennellii (Corr.) D'Arcy (rich in trichomes) and its F1 hybrid with L. esculentum (Mill.) have been recorded compared to cultivated tomato, L. esculentum (poor in trichomes). Leaf miners are also negatively affected by latex and density of trichomes in Asclepias spp. (Agrawal 2004). Leaf trichomes are known to have a strong influence on the behavior, selection, and performance of insect herbivores (Norris \& Kogan 1980; Woodman \& Fernandes 1991; Fernandes 1994). Otherwise, more work will be necessary to observe the effects of trichome density during site selection by Eurytoma females.

\section{REFERENCES}

Agrawal, A. A. 2004. Resistance and susceptibility of milkweed: competition, root herbivory, and plant genetic variation. Ecology 85: $2118-2133$.

Almeida, S. P.; C. E. B. Proença; S. M. Sano \& J. F. Ribeiro. 1998. Cerrado: espécies vegetais úteis. Planaltina, EMBRAPA-CPAC, $464 \mathrm{p}$.

Askew, R. R. \& J. Blasco-Zumeta. 1998. Insects associated with galls of a new species of Eurytomidae (Hymenoptera: Chalcidoidea) on Ephedra nebrodensis in Spain. Journal of Natural History 32: 805-821.

Auslander, M.; E. Nevo \& M. Inbar. 2003. The effects of slope orientation on plant growth, developmental instability and susceptibility to herbivores. Journal of Arid Environments 55: 405-416.

Brandão, M. \& M. L. Gavilanes. 1992. Espécies padronizadoras do cerrado mineiro e sua distribuição no estado. Informe Agropecuário 16: 5-11.

De Santis, L. \& G. W. Fernandes. 1989. Brazilian parasitoids of gallforming insects: two new chalcidoid species and host records. Entomological News 100: 29-36.

De Souza, A. L. T.; G. W. Fernandes; J. E. C. Figueira \& M. O. Tanaka. 1998. Natural history of a gall- inducing weevil Collabismus clitellae (Coleoptera: Curculionidae) and some effects on its host plant Solanum lycocarpum (Solanaceae) in southeastern Brazil. Annals of the Entomological Society of America 91: 404-409.

De Souza, A. L. T.; M. O. Tanaka; G. W. Fernandes \& J. E. C. Figueira. 2001. Host plant response and phenotipic plasticity of a galling weevil (Collabismus clitellae: Curculionidae). Austral Ecology 26: $173-178$.

Edwards, P. B. 1998. Seasonal abundance and parasitism of Mesoclanis seed flies (Diptera: Tephritidae) in South Africa, and implications for the biological control of Chrysanthemoides monilifera (Asteraceae) in Australia. Bulletin of Entomological Research 88: $407-414$.

Eliason, E. A. \& D. A. Potter. 2001. Spatial distribution and parasitism of leaf galls induced by Callirhytis cornigera (Hymenoptera: Cynipidae) on pin oak. Environmental Entomology 30: 280-287.

Feng, H. G.; K. M. Wu; D. F. Cheng \& Y. Y. Guo. 2004. Northward migration of Helicoverpa armigera (Lepidoptera : Noctuidae) and other moths in early summer observed with radar in northern China. Journal of Economical Entomology 97: 1874-1883.

Feng, H. G.; K. M. Wu; Y. X. Ni; D. F. Cheng \& Y. Y. Guo. 2005. Highaltitude windborne transport of Helicoverpa armigera (Lepidoptera: Noctuidae) in mid-summer in northern China. Journal of Insect Behaviour 18: $335-349$.

Fernandes, G. W. \& P. W. Price. 1988. "Biogeographical gradients in galling species richness: tests of hypotheses. Oecologia 76: 161167. 
Fernandes, G. W. 1990. Hypersensitivity: a neglected plant resistance mechanism against insect herbivores. Environmental Entomology 19: 1173-1182.

Fernandes, G. W. \& P. W. Price. 1992. The adaptive significance of insect gall distribution: survivorship of species in xeric and mesic habitats. Oecologia 90: 14-20.

Fernandes, G. W. 1994. Plant mechanical defenses against insect herbivory. Revista Brasileira de Entomologia 38: 421-433.

Fernandes, G. W.; M. Fagundes; R. L. Woodman \& P. W. Price. 1999. Ant effects on three-trophic level interactions: plant, galls, and parasitoids. Economical Entomology 24: 411-415.

Fernandes, G. W.; T. G. Cornelissen; R. M. S. Isaias \& A. F. Lara. 2000. Plants fight gall formation: hypersensitivity. Ciência e Cultura 52: $49-54$.

Fernandes, G. W.; S. J. Gonçalves-Alvim \& M. A. A. Carneiro. 2005. Habiat-driven effects on the diversity of gall-inducing insects in the Brazilian Cerrado. p. 693-708. In: A. Raman, C. W. Schaefer \& T. M. Withers (eds) Biology, Ecology, and Evolution of Gallinducing Arthropods. vol. 2. Science Publishers Inc.

Georgiev, G. T. \& A. M. Stojanova. 2003. New Chalcidoidea (Hymenoptera) parasitoids of Dasineura saliciperda (Dufour) (Diptera: Cecidomyiidae) in Bulgaria. Journal of Pest Science 76: $161-162$.

Hale, M. L.; Z. Acs \& G. N. Stone. 2004. Polymorphic microsatellite loci in Eurytoma brunniventris, a generalist parasitoid in oak cynipid galls. Molecular Ecology Notes 4: 197.

Hartman, H. 1984. Ecology of gall-forming Lepidoptera on Tetradymia. 1. gall size and shape. 2. plant stress effects on infestation intensity. 3. within-plant horizontal and vertical-distribution. Hilgardia 52: $1-39$.

Hawthorne, D. J.; J. A. Shapiro; W. M. Tingey \& M. A. Mutschler. 1992. Trichome-borne and artificially applied acylsugars of wild tomato deter feeding and oviposition of the leafminer Liriomyza trifolii. Entomologia Experimentalis et Applicata. 65: 65-73.

Hayman, D. I.; K. E. Mackenzie \& E. G. Reekie. 2003. The influence of pruning on wasps inhabitants of gall's induced by Hemadas nubilipennis Ashmead (Hymenoptera: Pteromalidae) on lowbush blueberry. Journal of Economical Entomology 96: 1245-1253.

Johannesen, J. \& A. Seitz. 2003. Larval distributions of the ectoparasitoid wasp Eurytoma robusta relative to the host tephritid gall fly Urophora cardui. Entomologia Experimentalis et Applicata 107: 47-55.
Lopes, P. S. N.; J. C. Souza; P. R. Reis; J. M. Oliveira \& I. D. F. Rocha. 2003. Caracterização do ataque da broca dos frutos do pequizeiro. Revista Brasileira de Fruticultura 25: 540-543.

Norris, D. M. \& M. Kogan. 1980. Biochemical and morphological bases of resistance. F. G. Maxwell \& P. R. Jennings (eds). Breeding plants resistance to insects. New York, J. Wiley, p. 23-61.

Oliveira, P. S. 1997. The ecological function of extrafloral nectaries: herbivore deterrence by visiting ants and reproductive output in Caryocar brasiliense (Caryocaraceae). Functional Ecology 11: 323-330.

Pathak, S. C.; V. Kulshrestha; A. K. Choubey \& A. H. Parulekar. 1999. Insect drift over the northern Arabian sea in early summer. Journal of Bioscience 24: 233-240.

Rezende, M. H. 1998. Anatomia dos órgãos vegetativos, da flor e estruturas secretoras de Caryocar brasiliense Camb. (Caryocaraceae). São Paulo, 1998. 91p. DSc Dissertation. São Paulo, Universidade de São Paulo.

Ribeiro, R. F. 2000. Pequi, o rei do cerrado: roendo o fruto sertanejo por todos os lados. Belo Horizonte, Rede Cerrado/ Rede/Caanm/Campo Vale, $62 \mathrm{p}$.

Roininen, H.; P. W. Price \& J. Tahvanainen. 1996. Bottom-up and top-down influences in the trophic system of a willow, a galling sawfly, parasitoids and inquilines. Oikos 77: 44-50.

Sano, S. M. \& S. P. Almeida. 1998. Cerrado: ambiente e flora. Planaltina, EMBRAPA-CPAC, $556 \mathrm{p}$.

Schooley, R. L. \& J. A. Wiens. 2003. Finding habitat patches and directional connectivity. Oikos 102: 559-570.

Tagawa, J. \& H. Fukushima. 1993. Effects of host age and cocoon position on attack rate by the hyperparasitoid, Eurytoma sp. (Hym., Eurytomidae), on cocoons of the parasitoid, Cotesia (= Apanteles) glomerata (Hym., Braconidae). Entomophaga 38: 69-77.

Tixier, M. S.; S. Kreiter \& P. Auger. 2000. Colonization of vineyards by phytoseiid mites: their dispersal patterns in the plot and their fate. Experimental and Applied Acarology 24: 191-211.

Whitham, T. G. 1978. Habitat selection by Pemphigus aphids in response to resource limitation and competition. Ecology 59: $1164-1176$.

Woodman, R. L. \& G. W. Fernandes. 1991. Differential mechanical defense: herbivory, evapotranspiration, and leaf hairs. Oikos 60: 11-19.

Received 14/08/2007; accepted 15/10/2009 